Jacek Kulbaka

Warszawa

\title{
Dzialalność Sekcji Szkolnictwa Specjalnego Związku Nauczycielstwa Polskiego na rzecz ksztalcenia specjalnego w pierwszym dziesięcioleciu po II wojnie światowej
}

\section{Rodowód Sekcji Szkolnictwa Specjalnego}

Początki Sekcji Szkolnictwa Specjalnego ZNP (dalej SSS ZNP) sięgają czasów II Rzeczypospolitej. Był to okres, w którym młode państwo polskie niemal od podstaw musiało zająć się problematyką opieki i kształcenia niepełnosprawnych. Bezsprzecznie w dziale szkolnictwa specjalnego momentem przełomowym było utworzenie w $1922 \mathrm{r}$. Państwowego Instytutu Pedagogiki Specjalnej (PIPS). Instytut ten prowadził zarówno badania naukowe w zakresie: upośledzonych umysłowo, niewidomych, głuchych i moralnie zaniedbanych (wg ówczesnej terminologii), jak i zajmował się przygotowaniem zawodowym nauczycieli szkół specjalnych. Do 1958 r. była to jedyna tego typu placówka w Polsce.

Stojąca na czele PIPS Maria Grzegorzewska już w drugim roku działalności Instytutu ustanowiła Ognisko Szkolne, którego celem było m.in.: omawianie i dyskutowanie zagadnien' dydaktyczno-wychowawczych i opieki nad dzieckiem anormalnym [...] oraz gromadzenie $i$ kompletowanie materialów uzasadniających potrzebę powolania Sekcji Szkolnictwa Specjalnego przy Zwiqzku Polskiego Nauczycielstwa Szkót Powszechnych'.

Niemal w tym samym czasie absolwentki pierwszego rocznika PIPS: Józefa Bauman, Zofia Hoffman i Irena Soniorowska, z własnej inicjatywy utworzyły w Lodzi pierwszą terenową Sekcję Szkolnictwa Specjalnego przy tamtejszym Zarządzie ZPNSP. Widziały konieczność powołania krajowej sekcji, reprezentującej interesy całego środowiska osób zajmujących się pedagogiką i szkolnictwem specjalnym.

W dniu 1 czerwca 1924 r. Wydział Wykonawczy Zwiazku Polskiego Nauczycielstwa Szkół Powszechnych powołał Ogólnokrajową Sekcję Szkolnictwa Specjalnego. Stanowisko przewodniczącej SSS ZPNSP powierzono M. Grzegorzewskiej, która funkcję tę piastowała niezmiennie do wybuchu II wojny światowej ${ }^{2}$.

Do nadrzędnych zadań pierwszego Zarządu SSS ZPNSP (ZNP) zaliczono: pogłębienie wiedzy z zakresu pedagogiki specjalnej, udoskonalenie metod nauczania i wychowa-

\footnotetext{
'Archiwum ZNP, syg. 711, s. 25 (z referatu Jana Rychlika, wygłoszonego na sesji naukowej poświęconej SSS ZNP w 1975 r.).

${ }^{2}$ I. Czarnecka, Dzialalność Sekcji Szkolnictwa Specjalnego ZNP na rzecz osób gluchych (niestyszacych i niedostyszacych) w latach 1946-2001, „Przegląd Historyczno-Oświatowy” nr 3-4, 2005, s. 170.
} 
nia anormalnych (niepełnosprawnych), popularyzacje potrzeb opieki nad nieletnimi oraz sprawowanie opieki nad materialnymi i prawnosłużbowymi potrzebami nauczycieli szkół specjalnych. Oprócz tego Sekcja zainicjowała badania naukowe w poszczególnych działach szkolnictwa specjalnego, organizowała zjazdy, kursy, odczyty i konferencje dla działaczy oświatowych i nauczycieli szkół specjalnych ${ }^{3}$.

Do Sekcji, obok nauczycieli szkół specjalnych, mogli i należeli nauczyciele szkół powszechnych oraz inne osoby związane ze środowiskiem osób niepełnosprawnych (lekarze, członkowie PIPS, działacze oświatowi i społeczni).

W grudniu 1924 r., staraniem SSS ZPNSP, wydany został pierwszy numer kwartalnika „Szkoła Specjalna”. Na czele komitetu redakcyjnego stanęła M. Grzegorzewska ${ }^{4}$.

Należy podkreślić, że Zarząd SSS ZPNSP był pomysłodawcą i współorganizatorem z MWRiOP i PIPS, dwóch zjazdów dla nauczycieli szkół specjalnych, w 1925 i 1934 r.

W I Zjeździe udział wzięło blisko 400 osób, w tym naczelnicy poszczególnych wydziałów resortu oświaty i 261 nauczycieli szkół specjalnych. Na forum Zjazdu oraz w podsekcjach wnikliwie omówiono stan i potrzeby szkolnictwa specjalnego w Polsce. W uchwałach pozjazdowych znalazły się zapisy o konieczności: wprowadzenia obowiązku szkolnego dla anormalnych, organizowania zakładów wychowawczych dla upośledzonych umysłowo, podjęcia przez władze samorządowe i przez organizacje społeczne akcji szkolenia zawodowego wśród niepełnosprawnych, rozbudowy struktur SSS ZPNSP w celu propagowania potrzeb szkolnictwa specjalnego w społeczeństwie. Nie zabrakło wniosku adresowanego do władz państwowych w sprawie przygotowania ustawy szkolnej dotyczącej ustroju szkolnictwa specjalnego ${ }^{5}$.

Głównym celem II Zjazdu Nauczycieli Szkół Specjalnych było: zespolenie pracy i nawiqzanie glębszego porozumienia wśród pracowników $w$ dziedzinie szkolnictwa specjalnego $w$ celu rozwoju zagadnień zarówno organizacji tego szkolnictwa, jak metod ksztalcenia i wychowania dzieci anormalnych ${ }^{6}$. W Zjeździe brało udział blisko 600 osób, w tym 450 nauczycieli szkół specjalnych. Ponownie wystapiono z postulatem opracowania ustawy o rozwoju szkolnictwa specjalnego, a ponadto wnioskowano o zwiększenie oddziałów i rozbudowę szkół specjalnych, zorganizowanie szkolenia zawodowego i zatrudnienia absolwentów szkół specjalnych. Sekcja, w interesie nauczycieli szkół specjalnych, domagała się lepszego wynagrodzenia i poprawy warunków ich pracy ${ }^{7}$.

3 „Szkoła Specjalna" nr 1, 1924, s. 1-3 (Zamiast programu).

${ }^{4}$ „Szkoła Specjalna” nr 4, 1974, s. 297 (do wybuchu wojny ukazało się 15 roczników pisma; druk gotowego 16 rocznika czasopisma wstrzymał wybuch wojny).

${ }^{5}$ M. Balcerek, Rozwój opieki nad dzieckiem $w$ Polsce 1918-1939, Warszawa 1978. W II RP nie wydano rozporządzeń wykonawczych do dekretu o obowiązku szkolnym z 1919 r. dla upośledzonych umysłowo. Niezadowalające były zarówno warunki lokalowe szkół specjalnych, jak i ich liczba w poszczególnych częściach kraju. W dziale upośledzonych (największym w szkolnictwie specjalnym) na 75 tys. dzieci wymagających opieki, w tym umieszczenia ich w szkołach specjalnych, w rzeczywistości przebywało w nich około $1800 \mathrm{dzieci}$, czyli $2,4 \%$ wszystkich potrzebujących.

${ }^{6}$ "Szkoła Specjalna” 1934/35, s. 49-56.

${ }^{7}$ Archiwum ZNP, syg. 711, s. 21 (referat H. Kopińskiego, Rola Marii Grzegorzewskiej w stworzeniu Sekcji Szkolnictwa Specjalnego). 


\section{Okres wojny, okupacji i odbudowy Sekcji Szkolnictwa Specjalnego do 1948 r.}

Wojna i okupacja doprowadziły do wstrzymania prac SSS ZNP, ale już z końcem 1944 r. Henryk Ryll, Kazimierz Kirejczyk, Franciszek Karpiński i Maria Grzegorzewska podjęli pierwsze próby jej reaktywowania. W pierwszej połowie 1945 r. wznowiła działalność Sekcja w okręgu łódzkim, a następnie w katowickim. Krajowa SSS ZNP rozpoczęła działalność 6 marca $1946 \mathrm{r}$.

Należałoby przypomnieć, że w czasie odbudowy struktur SSS ZNP - Henryk Ryll, Franciszek Karpiński oraz Kazimierz Kirejczyk prezentowali stan i potrzeby szkolnictwa specjalnego na forum I Ogólnopolskiego Zjazdu Oświatowego w Łodzi w 1945 r., a następnie podczas zjazdu zorganizowanego przez ZG ZNP w Bytomiu'

Owocem wystapienia Henryka Rylla podczas zjazdu łódzkiego, a było to pierwsze oficjalne wystapienie przedstawiciela Referatu Szkół Specjalnych Ministerstwa Oświaty, którego treść autor konsultował przed zjazdem z Marią Grzegorzewską była rezolucja, w której napisano, że: zjazd zwraca uwagę na konieczność zajęcia się sprawami szkolnictwa specjalnego i objecia go projektowanq opiekq szkolnq?.

W znakomitej większości dezyderaty, z którymi wystąili podczas zjazdów Ryll, Kirejczyk i Karpiński wychodziły naprzeciw postulatom SSS ZNP. Można by do nich zaliczyć sprawy: rozbudowy sieci przedszkoli, szkół podstawowych, zawodowych i liceów specjalnych, kwestie dokształcania i kształcenia kadr nauczycielskich, organizowania w placówkach szkolnictwa specjalnego właściwej opieki lekarskiej i higienicznej, zorganizowania adekwatnych do potrzeb selekcji i kwalifikowania dzieci do szkół i zakładów specjalnych oraz przygotowanie $\mathrm{i}$ wprowadzenie w życie ustawy o systemie szkolnictwa specjalnego.

Podobnie jak w okresie przedwojennym w prace SSS ZNP włączyli się doświadczeni nauczyciele, przedstawiciele Ministerstwa Oświaty i PIPS ${ }^{10}$.

Na pierwszym posiedzeniu Zarządu Głównego Sekcji, 6 marca 1946 r., stanowisko przewodniczącej, podobnie jak w okresie przedwojennym, powierzono Marii Grzegorzewskiej. Funkcje wiceprzewodniczącego objął Wacław Tułodziecki, a sekretarzem został Kazimierz Kirejczyk. Zarząd dyskutował m.in. na temat poprawy warunków bytowych nauczycieli i ich kształcenia oraz doskonalenia zawodowego. Szczegółowy harmonogram działalności SSS ZNP na lata 1944-1948 obejmował ponadto:

- zorganizowanie walnego zjazdu nauczycieli szkół specjalnych w 1946 r. (ostatni odbył się w 1934 r.),

\footnotetext{
${ }^{8}$ I Ogólnopolski Zjazd Oświatowy w Lodzi I8-22 czerwca 1945, Warszawa 1945, s. 208 i 229; na temat zjazdu w Bytomiu - Biuletyn Zarzqdu Krajowego Sekcji Szkolnictwa Specjalnego, Warszawa 1957 (artykul Stanisława Dziedzica).

${ }^{9}$ S. Mauersberg, M. Walczak, Oświata polska 1944-1956 (wybór źródel), cz. I, Warszawa 1999, s. 247.

${ }^{10} \mathrm{~K}$. Kirejczyk, Sześćdziesiqt lat spolecznej stużby dziecku niepelnosprawnemu, „Szkoła Specjalna” $\mathrm{nr} 1,1986$, s. 84-98 (lata 1944-1948 to okres bardzo dobrej dzialalności Sekcji. K. Kirejczyk uznal, że w tym okresie wywiązała się niepowtarzalna atmosfera i klimat dla odbudowy szkolnictwa specjalnego. Opinię tę sformułował co prawda po latach, ale w omawianym okresie pełnił on ważne funkcje w SSS ZNP oraz w Ministerstwie Oświaty - jako szef Wydziału Szkół Specjalnych); Zob. też W. Gasik, O ludziach Państwowego Instytutu Pedagogiki Specjalnej w siedemdziesięciolecie placówki, „Szkoła Specjalna” nr 4, 1992, s. 147-152 (Maria Grzegorzewska za życia stała się „filarem” szkolnictwa specjalnego. Kierowała PIPS, aktywnie uczestniczyła w pracach Referatu i Wydziału Szkół Specjalnych Ministerstwa Oświaty, stała na czele Sekcji, prowadziła działalność wydawnicza, organizowala kursy szkoleniowe i konferencje $w$ ramach szkolnictwa specjalnego).
} 
- podjęcie starań o stopniowe upowszechnienie obowiązku szkolnego wśród dzieci niewidomych i głuchych,

- prace nad zorganizowaniem szkolnictwa zawodowego we wszystkich typach szkół i zakładów specjalnych,

- rozplanowanie, we współpracy z Ministerstwem Oświaty, sieci zakładów specjalnych,

- współpracę z Ministerstwem Pracy i Opieki Społecznej oraz z Ministerstwem Oświaty w sprawie zatrudnienia niewidomej młodzieży w warsztatach przemysłowych,

- akcję wspierania inicjatyw budowy szkół i sanatoriów dla dzieci chorych,

- wprowadzenie zagadnień pedagogiki specjalnej do tematyki organizowanych w Polsce kursów pedagogicznych ${ }^{11}$.

Środki finansowe, jakimi dysponował Zarząd SSS ZNP, pochodziły z subwencji ministerialnych. W roku szkolnym 1946/1947 Sekcja zabiegała o przyznanie kwoty 758 tys. zł, z czego 300 tys. zł miało być przeznaczone na wznowienie „Szkoły Specjalnej", dalsze 208 tys. na prace badawcze i publikacje własne oraz 200 tys. na organizacje kongresu nauczycieli szkół specjalnych. Szczegółowe plany wydatków Sekcji w latach 1946/47, 1947/48 i 1949/49 przedstawiają tabele:

Tabela 1. Szczegółowe zestawienie wydatków SSS ZNP w roku szkolnym 1946/47

\begin{tabular}{|l|c|}
\hline 1. Prace badawcze, odczyty, artykuły, prelekcje, poradnictwo & 208 tys. zł \\
\hline 2. Prace naukowe & 50 tys. zł \\
\hline 3. Wydawnictwo „Szkoła Specjalna” & 300 tys. zł \\
\hline 4. Kongres nauczycieli szkół specjalnych & 200 tys. zł \\
\hline \multicolumn{1}{|c|}{ Razem } & 758 tys. zł \\
\hline
\end{tabular}

Źródło: Arch. ZNP, SSS, syg. 679, s. 227.

Tabela 2. Zestawienie planowanych wydatków SSS ZNP na lata 1947/1948 i 1948/1949

\begin{tabular}{|c|c|c|}
\hline Wyszczególnienie wydatków & Rok szkolny $1947 / 1948$ & Rok szkolny $1948 / 1949$ \\
\hline Płace pracowników Sekcji & 30 tys. & 36 tys. \\
\hline Prace naukowo-badawcze & 180 tys. & 240 tys. \\
\hline Wydatki kancelaryjne & 120 tys. & 120 tys. \\
\hline Zjazd nauczycieli szkół specjalnych & $\begin{array}{c}200 \text { tys. } \\
\text { (sale, administracja, wyżywienie itd.) }\end{array}$ & 800 tys. \\
\hline Kursy dla nauczycieli szkół specjalnych & 200 tys. & 700 tys. \\
\hline „Szkoła Specjalna” & 500 tys. (4 kwartaly po 125 tys.) & 500 tys. \\
\hline Razem & 1230 tys. $\mathrm{zt}$ & 2396 tys. zl \\
\hline
\end{tabular}

Źródło: Arch. ZNP, syg. 679, s. 219.

${ }^{11}$ Arch. ZNP, Sekcja Szkolnictwa Specjalnego (dalej SSS), syg. 69, s. 1-6. 
Niestety nie wszystkie środki finansowe, o jakie zabiegała SSS ZNP w latach 1946-48, zostały jej przyznane przez Ministerstwo Oświaty. Szczególnie niekorzystnie odbiło się to na działalności wydawniczej. W latach 1946-1948 ukazały się zaledwie dwa roczniki „Szkoły Specjalnej”. Mimo to w przedmowie do 16 tomu „Szkoły Specjalnej”, z sierpnia 1946 r., Maria Grzegorzewska z nadzieją pisała: pójdziemy dalej nakreślonymi przez nas szlakami teorii, organizacji i praktyki szkoly specjalnej [...] $w$ zwiqzku z reforma życia gospodarczego i spolecznego kraju naszego oraz reforma szkolnq, doniostość pracy naszej w dziedzinie szkolnictwa specjalnego zarysowała się jeszcze wymowniej ${ }^{12}$.

Pierwszy numer czasopisma miał charakter sprawozdawczy. Informowano w nim o losach szkolnictwa specjalnego w dobie wojny i okupacji oraz o perspektywach rozwoju w powojennej Polsce. Grzegorzewska przedstawiła informacje na temat PIPS, Henryk Ryll omawiał prace Ministerstwa Oświaty na polu szkolnictwa specjalnego, Leokadia Frydrychowska i Kazimierz Kirejczyk scharakteryzowali prace Sekcji w okresie przedwojennym ${ }^{13}$. Kolejny numer „Szkoły Specjalnej” ukazał się jako rocznik i choć za przyczynę takiego stanu rzeczy podano przeszkody natury technicznej, to nie ulega wątpliwości, że zabrakło środków finansowych ${ }^{14}$. Ostatecznie po dwóch latach druk "Szkoły Specjalnej” został całkowicie wstrzymany ${ }^{15}$. Środowisko osób zwiazanych ze szkolnictwem specjalnym straciło ważne i jedyne czasopismo, na łamach którego prezentowane były artykuły metodyczne i obszerne sprawozdania z konferencji i kursów organizowanych przez Sekcję Szkolnictwa Specjalnego.

Pomimo trudności finansowych towarzyszących pracom pierwszego Zarządu SSS ZNP dwa pierwsze lata jego działalności można jednak uznać za udane.

Zarząd Sekcji brał udział w wielu inicjatywach i dyskusjach organizowanych przez PIPS i Referat, a następnie (od 1947 r.) Wydział Szkół Specjalnych Ministerstwa Oświaty. Wspólnie omawiano sprawy dotyczące finansowania szkół specjalnych, kształcenia nauczycieli, selekcji, metod pracy itd.

W dniu 16 września $1946 \mathrm{r}$. Ministerstwo Oświaty, na wniosek i w porozumieniu z Sekcja, wydało zarządzenie $W$ sprawie dodatku shuzbowego dla wybitnych fachowców w szkolach specjalnych ${ }^{16}$. W myśl tego zarządzenia, począwszy od roku szkolnego 1946/47, nauczyciele szkół specjalnych, kierownicy oraz instruktorzy w szkołach zawodowych specjalnych, mogli otrzymać dodatek aż do $100 \%$ wyższy od bazowego wynagrodzenia. Zarządzenie nie dotyczyło pedagogów nieposiadających kwalifikacji

\footnotetext{
12 ,Szkoła Specjalna” nr 4, 1974, s. 297 (do 1939 r. ukazało się 15 roczników pisma.

${ }^{13}$ Ibidem, s. 12, 38.

${ }^{14}$ "Szkoła Specjalna" nr 1-4, 1947/1948.

${ }^{15} \mathrm{~K}$. Kirejczyk, ZNP - Sekcja Szkolnictwa Specjalnego so lat pracy. Dla przyszlości dzieci upośledzonych, Warszawa 1974, s. 111-113 (w zbiorach własnych Arch. ZNP) (według K. Kirejczyka główną przyczyną wstrzymania druku „Szkoły Specjalnej” było załamanie się współpracy między ZNP a Ministerstwem Oświaty oraz to, że Sekcja nie porozumiała się z ZG ZNP w sprawie ostatecznej formuły pisma. Druk „Szkoły Specjalnej” wznowiło Ministerstwo Oświaty w 1957 r.).

${ }^{16}$ Dziennik Urzędowy Ministerstwa Oświaty (dalej: Dz.U.M.O.), 1946, nr 11, poz. 326 i Dz.U.M.O., 1947, nr 2, poz. 49 (kolejny komunikat w sprawie dodatku służbowego dla wybitnych fachowców w szkołach specjalnych).
} 
zawodowych uprawniających do pracy w szkolnictwie specjalnym, zgodnie z zarządzeniem MWRiOP z 15 czerwca 1929 r. $^{17}$

Sekcja i Ministerstwo Oświaty podejmowały wspólne działania na rzecz zorganizowania kształcenia zawodowego w szkołach dla upośledzonych umysłowo. Odwoływano się do pionierskich tego typu rozwiązań wywodzących się $\mathrm{z}$ dwudziestolecia międzywojennego. Warto nadmienić, że w tym czasie w Polsce, jak i w Europie, nie było aktów prawnych normujących kształcenie zawodowe dzieci i młodzieży upośledzonej umysłowo ${ }^{18}$. Sekcja postulowała, by prace programowe, w zakresie kształcenia zawodowego w szkołach dla upośledzonych umysłowo, zmierzały do przekształcenia szkoły specjalnej typu ogólnokształcącego w szkolę ogólnokształcącą zawodową. Dla uczniów klas szóstych szkoły podstawowej opracowano program zajęć w warsztatach szkolnych, w wymiarze 12 godzin tygodniowo, przy jednoczesnym skróceniu czasu nauki z przedmiotów ogólnokształcących do 24 godzin. W klasach siódmej i ósmej zajęcia warsztatowe miały obejmować juz 18 godzin tygodniowo (na równi $\mathrm{z}$ wymiarem przedmiotów ogólnokształcących). Dla absolwentów szkół podstawowych przewidywano dalsze kształcenie w szkołach zawodowych specjalnych w zakresie zawodów rękodzielniczych.

Sprawa przysposobienia i kształcenia zawodowego upośledzonych umysłowo i innych kategorii niepełnosprawności znalazła odbicie w zarządzeniach i instrukcjach programowych Ministerstwa Oświaty. W roku szkolnym 1947/48 Ministerstwo Oświaty uruchomiło 2 pierwsze szkoły zawodowe specjalne dla młodzieży niewidomej oraz 4 szkoły dla głuchoniemych, 2 dla upośledzonych umysłowo i dla młodzieży moralnie zaniedbanej 7 szkół $^{19}$.

W Instrukcji Ministerstwa Oświaty z 29 maja 1947 r. znalazł się zapis o tworzeniu przedszkoli specjalnych. Była to bardzo ważna i potrzebna decyzja, zgodna z postulatami działaczy SSS ZNP. Pierwsze przedszkola specjalne rozpoczęły pracę w roku szkolnym $1947 / 48$, szkoda tylko, że ich rozbudowa postępowała w bardzo wolnym tempie ${ }^{20}$.

Sekcja pozytywnie zaopiniowała też zarządzenie Ministra Oświaty z 3 czerwca 1948 r., w sprawie Selekcji dzieci umyslowo upośledzonych i kierowania ich do zakladów, szkót $i$ oddzialów specjalnych dla upośledzonych ${ }^{21}$. Treść tego zarządzenia, jak i załączonej do niego szczegółowej instrukcji, Ministerstwo konsultowało z M. Grzegorzewską, która bardzo stanowczo podkreślała, iż w toku postępowania selekcyjnego należy przyjrzeć się przede wszystkim środowisku dziecka, po to, aby wykluczyć przypadki wadliwego kwalifikowania dzieci do placówek szkolnictwa specjalnego ${ }^{22}$.

\footnotetext{
${ }^{17}$ Dz.U. RP, 1929, nr 49, poz.105.

${ }^{18}$ H.Ryll, Odbudowa szkolnictwa specjalnego w okresie powojennym, „Szkoła Specjalna” R.1946/1947, nr 1-4, s. 12-24 (przed wojną spośród 63 szkół dla upośledzonych umysłowo w 20 zorganizowano warsztaty: szewskie, stolarskie, introligatorskie, bieliźniarskie i gospodarstwa domowego dla 518 uczniów).

${ }^{19}$ Dzienniki Urzędowe Ministerstwa Oświaty 1947, nr 6, poz. 135 i 1948, nr 6, poz. 113; Zob. Szkolnictwo w roku szkolnym 1947/48 w liczbach tymczasowych, z. 6, Warszawa GUS 1948, s. 6 (Biuro Badań i Statystyki Ministerstwa Oświaty).

${ }^{20}$ Dz.U.M.O, 1947, nr 6, poz. 135; Zob. Archiwum Akt Nowych (dalej AAN), Ministerstwo Oświaty, syg. 1441, s. 192; Zob. Szkolnictwo w roku szkolnym $1947 / 48$ w liczbach tymczasowych, z. 6, Warszawa GUS 1948.

${ }^{21}$ Dz.U.M.O., 1948, nr 6, poz. 108.

${ }^{22}$ AAN, Ministerstwo Oświaty, syg. 1732, s. 155.
} 
SSS ZNP, na mocy zarządzenia Ministerstwa Oświaty z 1945 r., była uprawniona do organizowania konferencji i szkoleń dla nauczycieli szkół specjalnych. Taki kierunek działalności Sekcji stanowił w latach 1946-48 bez wątpienia jej najmocniejszą stronę.

Pierwszy kurs zorganizowano w Zakopanem, w dniach od 1 do 15 sierpnia 1946 r. Kurs stanowił dla nauczycieli doskonałą okazję do zawiązania, odnowienia i pogłębienia znajomości, a także zapoznania się z kierunkiem prac resortu oświaty w szkolnictwie specjalnym. Obok Marii Grzegorzewskiej, Henryka Ryllả i Władysława Woźnickiego, Kazimierza Kirejczyka (kierownik kursu), brało w nim udział 55 nauczycieli reprezentujących poszczególne działy szkolnictwa specjalnego. Zebrani z optymizmem wypowiadali się na temat przyszłości szkolnictwa specjalnego w Polsce. Dyskutowano m.in. na temat pracy zawodowej absolwentów szkół specjalnych. Ubolewano nad znikomą znajomością problematyki szkolnictwa specjalnego w społeczeństwie.

Występująca na forum zjazdu Leokadia Frydrychowska, w nawiązaniu do okresu przedwojennego, mówiła o wspaniałej atmosferze pracy w PIPS, a w szczególności o osobie Marii Grzegorzewskiej i jej zasługach dla szkolnictwa specjalnego. Z ramienia Ministerstwa Oświaty występował Henryk Ryll. Jego referat na temat metod pracy w szkołach specjalnych wywołał ożywioną reakcję słuchaczy. Autor twierdził w nim, że w szkolnictwie specjalnym nie powinien i nie może być wprowadzony „urzędowo" program nauczania. Według niego powinno się zachować indywidualizację metod i treści nauczania, zależnie od typów szkół i zakładów specjalnych. Władysław Woźnicki przedstawił kierunki prac resortu oświaty, m.in. w zakresie: przygotowania kwalifikowanych nauczycieli, rozbudowy szkół i zakładów specjalnych, druku podręczników i pomocy szkolnych.

Uczestnicy zakopiańskiego kursu byli zgodni, że wychowanie oraz kształcenie dzieci i młodzieży specjalnej troski i opieka nad nimi winny stanowić jeden z priorytetów polityki oświatowej państwa. Mówiono o potrzebie profilaktyki i koordynacji prac różnorodnych instytucji społeczno-samorządowych. Zaproponowano powołanie, poza strukturami Ministerstwa Oświaty, organu koordynującego badania naukowe oraz leczenie matki i dziecka. Domagano się $e^{23}$ :

- zapewnienia kwalifikowanych kadr i poprawienia warunków materialnych nauczycieli we wszystkich szkołach specjalnych,

- wprowadzenia dla głuchych i niewidomych oraz przedłużenia dla upośledzonych umysłowo obowiązku szkolnego do 18 roku życia,

- przekazania dzieci podsądnych Ministerstwu Oświaty,

- zlikwidowania oddziałów specjalnych zorganizowanych przy zwykłych szkołach powszechnych, przy jednoczesnej rozbudowie szkół specjalnych,

- opracowania zarysu programu dla podstawowych szkół specjalnych i szkół specjalnych zawodowych,

- wprowadzenia zeszytów biograficznych Marii Grzegorzewskiej do wszystkich szkół specjalnych,

- zorganizowania opieki psychologicznej dla uczniów szkół specjalnych,

${ }^{23}$ K. Kirejczyk, ZNP - Sekcja..., s. 100-105; Zob. też. L. Frydrychowska, K. Kirejczyk, Prace Sekcji Szkolnictwa Specjalnego przy Zarzqdzie Glównym ZNP, „Szkoła Specjalna” nr 1-4, 1946/47, s. 31-38; Zob. K. Kirejczyk, Sześćdziesiqt lat spolecznej slużby dziecku niepelnosprawnemu, „Szkola Specjalna” nr 1, 1986, s. 84-89 (podaje inny termin kursu - w dniach od 1 do 15 lipca). 
- przygotowania testów do badania inteligencji głuchych, moralnie zaniedbanych, niewidomych oraz do badań psychotechnicznych,

- zorganizowania powiatowych pracowni psychologicznych, poradni ortofonicznych i poradni pedagogiki leczniczej,

- zapewnienia uczniom szkół specjalnych opieki lekarskiej, psychiatrycznej i higienicznej,

- upowszechnienia akcji dożywiania uczniów szkół specjalnych,

- utworzenia nowych form samokształcenia nauczycieli oraz zainicjowania prac badawczych poświęconych tematyce szkół specjalnych,

- stypendiów dla najzdolniejszych nauczycieli szkół specjalnych umożliwiających doskonalenie zawodowe w Polsce i za granica,

- organizacji wycieczek zagranicznych dla nauczycieli w celu zapoznania się z metodami pracy szkół specjalnych w innych krajach,

- organizowania corocznych kursów doszkalających dla nauczycieli szkół specjalnych,

- organizowania zjazdów i kongresów z udziałem najwybitniejszych polskich psychologów i pedagogów,

- rozbudowy szkolnictwa specjalnego w regionach wiejskich.

Sekcja miała swój wielki wkład w zakładaniu pierwszych szkół specjalnych dla kalek i przewlekle chorych. Już w 1946 r. prowadziła rozmowy w sprawie utworzenia takiej szkoły z dr Starkiewiczem, dyrektorem sanatorium dla dzieci w Busku-Zdroju. Sanatorium w Busku miało stanowić poligon doświadczalny w zakresie leczenia i wychowania. W porozumieniu z PIPS i Ministerstwem Oświaty planowano powołanie nowego działu kształcenia dla nauczycieli szkół sanatoryjnych.

Wszystkie te postulaty i formy współdziałania z Ministerstwem Oświaty doprowadziły do utworzenia, w roku szkolnym 1946/1947, 20 pierwszych szkół podstawowych specjalnych dla dzieci kalekich i przewlekle chorych, w których znalazło się miejsce dla około 1,5 tys. dzieci ${ }^{24}$.

SSS ZNP, dzięki wsparciu finansowemu Ministerstwa Oświaty i Ministerstwa Zdrowia, w dniach od 9 do 30 kwietnia 1947 r., zorganizowała kursokonferencję dla lekarzy i psychologów w sanatorium „Górka”, w Busku-Zdroju ${ }^{25}$. Dyskutowano na temat opieki i wychowania dzieci chorych przebywających w szpitalach i sanatoriach. Program konferencji obejmował m.in.:

- wprowadzenie słuchaczy w powojenną rzeczywistość polityczna,

- omówienie schorzeń dziecięcych i sposobów leczenia,

- przedstawienie psychologii dziecka przewlekle chorego,

- szczegółowe omówienie zajęć lekcyjnych i pozalekcyjnych.

Zebrani na kursokonferencji lekarze i psycholodzy ubiegali się o:

- zmiane, stosowanych w praktyce, nazw „sanatorium" i „prewentorium" na ,zakład leczniczo-wychowawczy" i „zapobiegawczy zakład leczniczo-wychowawczy”,

\footnotetext{
${ }^{24}$ Statystyka PRL, z. 67, Warszawa GUS 1962 ; AAN, Ministerstwo Oświaty, syg. 7685 i 7687.

${ }^{25} \mathrm{~K}$. Kirejczyk, Kurs - konferencja dla pracowników pedagogicznych oraz lekarzy zakladów $i$ sanatoriów dla dzieci przewlekle chorych $i$ kalekich, "Szkoła Specjalna”, 1947/48, nr 1-4, s. 75-83 (kursokonferencję tee zorganizowano przy wsparciu finansowym Ministerstwa Oświaty (75 tys. zł) i Ministerstwa Zdrowia (150 tys. zł)).
} 
- uruchomienie przynajmniej jednego w każdym województwie zakładu leczniczo-wychowawczego (gruźlica gruczołowa i naciekowa) oraz kilku sanatoriów-izolatorów (ciężka zakaźna gruźlica płuc),

- zorganizowanie dwóch zakładów specjalnych w Bytomiu i Świebodzinie dla dzieci i młodzieży kalekiej,

- rozbudowę przez Ministerstwo Oświaty zakładów dla chłopców epileptycznych w Brwinowie i Krakowie,

- zaproszenie lekarzy, pedagogów, higienistek i wychowawców na rady pedagogiczne do szkół,

- rozwijanie zajęć pozalekcyjnych w szkołach sanatoryjnych,

- upowszechnianie w szkołach metody ośrodków zainteresowań,

- uruchomienie w PIPS działu kształcenia dla personelu pedagogiczno-leczniczego,

- wcześniejsze przechodzenie na emeryturę nauczycieli szkół specjalnych,

- powołanie przez Ministerstwo Oświaty Komitetu Organizacyjnego „Zrzeszenie Dziecięcych Zakładów Leczniczo-Wychowawczych w Polsce".

Wszystkie uwagi przesłane zostały do wiadomości Ministerstwa Oświaty i Ministerstwa Zdrowia. Niewatpliwą zdobyczą tego spotkania było włączenie na trwałe tworzącego się szkolnictwa dla przewlekle chorych, w struktury organizacyjne Ministerstwa Oświaty oraz Sekcji Szkolnictwa Specjalnego ${ }^{26}$.

Kolejny kurs $\mathrm{z}$ inicjatywy Sekcji zorganizowano dla wizytatorów i kierowników szkół specjalnych, na przełomie lipca i sierpnia 1947 r. w Międzyzdrojach. Wzięło w nim udział 160 osób reprezentujących środowisko nauczycielskie, związkowe i ministerialne, w tym prelegenci-profesorowie: S. Baley, J. Konopczyński, M. Kreutz ${ }^{27}$. Kurs stanowił doskonałą okazję do omówienia spraw organizacyjnych szkolnictwa specjalnego i odegrał w pełni pozytywną rolę w zakresie zapoznania kierownictwa szkół specjalnych z planami reformatorskimi Ministerstwa Oświaty w szkolnictwie specjalnym. Był to ostatni kurs zorganizowany przez I Zarząd Sekcji Szkolnictwa Specjalnego.

Organizację kursów kontynuował również następny zarząd, który już w drugim miesiącu działalności zorganizował, w dniach od 5 do 28 kwietnia 1948 r., kurs w Rabce i Zakopanem. Wzięli w nim udział nauczyciele zatrudnieni w placówkach służby zdrowia. Zajmowano się metodami leczenia i nauczania w sanatoriach ze szczególnym uwzględnieniem gruźlicy kostno-stawowej, która należała do najczęstszych i najgroźniejszych schorzeń dziecięcych w okresie powojennym. Sformułowano szereg wniosków, które dotyczyły poprawienia pracy szkół specjalnych organizowanych w sanatoriach. Przekazano je następnie do Ministerstwa Oświaty i Ministerstwa Zdrowia. Przyjęto założenie, że:

- drogowskazem pracy wychowawczej jest dobre samopoczucie dziecka,

- oznaką nieprzydatności do pracy wychowawczej jest złe samopoczucie wychowawcy,

\footnotetext{
${ }^{26}$ Ibidem, s. 75-83 (wykaz referatów wygłoszonych na konferencji); Arch. ZNP, syg. 679 (sprawozdanie z konferencji, kursów, plany pracy); Zob. G. Kornet, Okres II wojny światowej i Polski Ludowej, w: E. Żabczyńska (red.), Maria Grzegorzewska pedagog w stużbie dzieci niepelnosprawnych, Warszawa 1995, s. 38 (M Grzegorzewska otworzyła konferencję w Busku-Zdroju. Wyglosiła dwa referaty: Zagadnienie szkolnictwa specjalnego i rola nauczyciela wychowawcy w tym szkolnictwie i Prady pedagogiczne za granica).

${ }^{27}$ K. Kirejczyk, Kurs nauczycieli i kierowników szkót specjalnych w Międzyzdrojach, „Szkoła Specjalna”, 1947/1948, nr 1-4, s. 84-86.
} 
- współpraca całego personelu jest fundamentem pracy całego zakładu,

- wychowawca winien dysponować odpowiednim lokalem na zajęcia świetlicowe,

- praca wychowawcza jest wartościowa tylko wtedy, gdy dziecko bierze w niej żywy udział,

- pracownicy zakładu powinni mieć możliwość uzupełniania kwalifikacji zawodowych,

- należy przekazać wykwalifikowanym wychowawcom kierownictwo i organizację zajęć pozaszkolnych,

- każdy wychowawca powinien prowadzić notatki z przebiegu pracy.

Mając na uwadze fakt, że wychowawcy nie byli nigdzie zrzeszeni, postulowano by włączyć ich do ZNP oraz określić i nadać im prawa uprawniające do świadczeń w miejscu zatrudnienia. Uznano, że czas pracy wychowawcy nie powinien przekraczać 8 godzin dziennie, a podstawą jego wykształcenia winna być tzw. mała matura $\mathrm{z}$ okresu międzywojennego. Ważnym zadaniem było ustalenie form kształcenia i dokształcania wychowawców (internaty, domy dziecka, zakłady specjalne). Planowano też wystosowanie do Ministerstwa Oświaty pisma z prośbą o przyznanie wychowawcom $50 \%$ dodatku do otrzymywanego wynagrodzenia ${ }^{28}$.

W lipcu 1948 r. II Zarząd Sekcji zorganizował w Cieszynie kurs szkoleniowy dla nauczycieli szkół specjalnych. Tym razem wzięło w nim udział 186 pedagogów. Było to pracowite spotkanie, bo w ciagu 3 tygodni kursu $2 / 3$ czasu przeznaczono na zajęcia warsztatowe $\mathrm{z}$ zakresu pedagogiki specjalnej $\mathrm{j}^{29}$.

Należy podkreślić, że wszystkie kursy szkoleniowe organizowane przez obydwa Zarządy Glówne SSS ZNP, we współpracy z Ministerstwem Oświaty, Ministerstwem Zdrowia i PIPS, przysłużyły się poważnie szkolnictwu specjalnemu. Ogółem, do końca 1948 r., wzięło w nich udział około tysiąca osób. Koszty organizacyjne wspomnianych kursów pokrywano $\mathrm{z}$ funduszów Ministerstwa Oświaty, a czasem ze środków Ministerstwa Zdrowia.

W praktyce wyodrębnił się podział na kursy wakacyjne przeznaczone dla wszystkich nauczycieli i wychowawców oraz kursy specjalistyczne, dla określonego działu szkolnictwa specjalnego. Szkoleniem nauczycieli szkół specjalnych nie zajmowały się w tym czasie Ośrodki Doskonalenia Nauczycieli (ODN).

Prace Sekcji zmierzały również w kierunku tworzenia przedstawicielstw w kuratoriach okręgów szkolnych, w postaci podsekcji. Pierwsza podsekcja powstała w Łodzi, w czerwcu 1945 r., a następne w: Katowicach, Warszawie, Krakowie, Lublinie i Toruniu. W pozostałych kuratoriach nie udało się utworzyć podsekcji, gdyż szkolnictwo specjalne było tam po prostu, ,jeszcze zbyt słabo rozwinięte" ${ }^{\text {"30 }}$.

Najtrudniejsza sytuacja występowała na Ziemiach Odzyskanych, na których Sekcja nie mogła prowadzić działalności w okresie przedwojennym. Podsekcje prowadziły kursy i szkolenia na własnym terenie. Nawiązały i podtrzymywały współpracę z kuratoriami

\footnotetext{
${ }^{28} \mathrm{~K}$. Kirejczyk, ZNP - Sekcja..., s. 100-105.

${ }^{29}$ Ibidem, s. 104-105.

${ }^{30}$ Arch. ZNP, Sprawozdanie z działalności w okresie od 29.11.1945 do 31.05.1948, Warszawa 1948 (sformułowanie pochodzi z posiedzenia Zarządu SSS ZNP). s. 13-14.; Zob. też Arch. ZNP, syg. 679 (sprawozdanie od 1.09.1946 do 1.11.1947 - m.in. Łódź i Chorzów, plany i osiągnięcia); Zob. też Szkolnictwo specjalne w Lodzi. Studia i materialy, Lódź 1974 (reaktywowanie Sekcji w Łodzi to zasługa J. Bytnara, E. Seniowa i J. Gucy).
} 
szkolnymi i PIPS. Organizowano też konferencje naukowe i prace w zespołach metodycznych oraz przygotowywano kandydatów do egzaminów w PIPS (oddziały krakowski, warszawski i katowicki).

W ciagu dwóch pierwszych lat działalności Sekcja aktywna była na wielu płaszczyznach, ale wydaje się, że najistotniejszą stroną jej działalności były konferencje szkoleniowe dla nauczycieli, które przyczyniły się też do podniesienia jakości pracy w szkolnictwie specjalnym ${ }^{31}$.

Za przyczyną SSS ZNP sprawą opieki lekarskiej i szkolnictwem dla przewlekle chorych w 1947 r. zainteresowała się Sejmowa Komisja Oświaty i Nauki. Posłowie brali udział w kilku posiedzeniach Komitetu Organizacyjnego Zespołu Sanatoriów Dziecięcych w Rabce ${ }^{32}$.

\section{Sekcja Szkolnictwa Specjalnego $w$ okresie ofensywy ideologicznej w oświacie i realizacji ustawy: $O$ sześcioletnim planie rozwoju gospodarczego $i$ budowy podstaw socjalizmu na lata 1950-1955}

Rok 1948 stanowi wyraźną cezurę w najnowszej historii Polski. Scenę polityczną kraju zdominował system jednopartyjny, oparty na przewodniej roli PPR, a od końca 1948 r. PZPR. Władza ludowa zrywając ostatecznie z pozorami demokracji rozpoczęła ofensywę ideologiczną prowadzoną we wszystkich możliwych obszarach życia społeczno-gospodarczego.

W szkolnictwie do niekorzystnych zjawisk należy zaliczyć uchwałę Rady Ministrów z 21 czerwca 1949 r., na mocy której Ministerstwo Oświaty utraciło kontrolę nad działem szkolnictwa zawodowego. Ten przekazano nowo powołanemu Centralnemu Urzędowi Szkolenia Zawodowego (CUSZ) ${ }^{33}$.

Na mocy ustawy z 20 marca 1950 r. O terenowych organach jednolitej władzy państwowej, powiatowe i wojewódzkie prezydia rad narodowych przejęły kompetencje kuratorów i inspektoratów szkolnych, które uległy rozwiązaniu. Decentralizacja aparatu szkolnego i wyjęcie go spod wpływów Ministerstwa Oświaty prowadziły do załamania administracji szkolnej. Na plan dalszy zepchnięto sprawy fachowości, kierownictwa i nadzoru, a co gorsza nowe urzędy administracji szkolnej zostały wielokrotnie podporządko-

\footnotetext{
${ }^{31}$ Arch. ZNP, Sprawozdanie..., s. 111 (opinię tę podzielal K. Kirejczyk, który uważał, że SSS zajmowała się „niechcianą" akcją szkolenia nauczycieli szkół specjalnych w dziale szkolnictwa dla upośledzonych umysłowo).

${ }^{32}$ AAN, Ministerstwo Oświaty, syg. 7669 i 1729; Zob. „Glos Nauczycielski” 1948, nr 2, 3, 4 (posiedzenia Sejmu I Kadencji); Zob. AAN, Kancelaria Sejmu Ustawodawczego RP (1947-1952), syg. 413 (skorowidz do sprawozdań stenograficznych Sejmu Ustawodawczego RP).

${ }^{33}$ Dz. Ustaw RP, 1949, nr 7, poz. 43; Zob. Dz. Ustaw RP, 1949, nr 40, poz. 283 (w sprawie kompetencji CUSZ); Zob. Dz. Ustaw RP, 1951, nr 36, poz. 277 (rozporządzenie Rady Ministrów w sprawie szkolnictwa zawodowego i prac CUSZ); Zob. AAN, Ministerstwo Oświaty, syg.1732, s. 290 (CUSZ otwierał i nadzorowal szkoły zawodowe specjalne, poza szkołami zawodowymi organizowanymi w zakładach wychowawczych oraz z wyłączeniem nielicznych szkół zawodowych specjalnych prowadzonych przez oddziały opieki nad dzieckiem Ministerstwa Oświaty); Zob. AAN, Ministerstwo Oświaty, syg. 283 (na mocy ustawy z 10.09.1956 r. CUSZ został rozwiazany: Dz. U.M.O., 1956, nr 41, poz. 143.).
} 
wane różnym szczeblom władzy ${ }^{34}$. Ostateczny kształt polityce oświatowej, na lata 1950-1955, nadała ustawa sejmowa z 21 lipca 1950 r. o sześcioletnim planie rozwoju gospodarczego $^{35}$.

Reforma systemu edukacji, prowadzona od końca lat 40., w dużej mierze polegała na mechanicznej recepcji doświadczeń pedagogicznych Związku Radzieckiego przy jednoczesnym odsunięciu rodzimej i zachodnioeuropejskiej myśli pedagogicznej ${ }^{36}$.

Kontroli państwa poddano organizacje związkowe. Na skutek reorganizacji i zmian statutowych ZNP utracił niezależność organizacyjną i został przemianowany na Związek Zawodowy Nauczycielstwa Polskiego (ZZNP). Związek stał się organizacją dyspozycyjną wobec Ministerstwa Oświaty ${ }^{37}$.

W toku postępującego upolitycznienia szkoły pod znakiem zapytania stanął dotychczasowy kierunek prac Sekcji Szkolnictwa Specjalnego. Perspektywy jej działalności nie były optymistyczne, skoro juz w pierwszym kwartale 1948 r. Ministerstwo Oświaty zawiesiło druk „Szkoły Specjalnej”. Zarząd SSS ZNP obawiał się, że następnym krokiem władz szkolnych może być całkowite wstrzymanie jej prac. O potrzebie istnienia Sekcji pisała Leokadia Frydrychowska, na łamach „Głosu Nauczycielskiego”. Twierdziła, że lata 1945-1948 były bardzo dobrym okresem tak dla Sekcji, jak i dla szkolnictwa specjalnego. Według niej, pomimo różnorakich trudności, szkolnictwo specjalne odbudowywane było $z$ pelnym zrozumieniem przez wladze szkolne $i$ wspierane autorytetem nauczyciela ${ }^{38}$.

\footnotetext{
${ }^{34}$ Dz. Ustaw RP, 1950, nr 14, poz. 130.; Zob. S. Mauersberg, M. Walczak, Szkolnictwo polskie po drugiej wojnie światowej (1944-1956), Warszawa 2005, s. 150 (we wstępie do ustawy pisano o: demokratyzacji Polski Ludowej przez jeszcze pelniejszy udzial mas pracujacych $w$ rzqdzeniu państwem $i$ skupienie $w$ radach narodowych pelni wladzy ludowej w terenie - w celu wzmocnienia Państwa Ludowego i przyśpieszenia budowy socjalizmu w Polsce [...]).

${ }^{35}$ Dz. Ustaw RP, 1950, nr 21, poz. 179. ; Zob. H. Minc, Osiagnięcia i plany gospodarcze, Warszawa 1948, s. 88-117; Zob. Dz. U.M.O, 1948, nr 6, poz. 113 (w Instrukcji z 10 czerwca 1948 r. w szkolnictwie specjalnym mowa jest o poglębieniu nastawienia ideowego nauczycieli do rzeczywistości politycznej); Zob. Dz. U.M.O, 1949, nr 9, poz. 165 (Instrukcja O organizacji roku szkolnego 1949/50); Zob. Dz. U.M.O, 1950, nr 14, poz. 175 (Instrukcja z 16 czerwca 1950 r. w szkolnictwie specjalnym).

${ }^{36} \mathrm{~K}$. Dobrzyński, Programy oświatowe polskiej radykalnej lewicy socjalistycznej i polityka oświatowa $P Z P R$, Warszawa 1982 (wg autora o ideologizacji szkoły można mówić już od 1947 r., kiedy to ukazała się praca M. Szulkina, Drogi rozwoju szkolnictwa radzieckiego). Na temat ideologizacji szkoły zobacz: B. Bierut, Podstawy ideologiczne zjednoczonej partii, „Trybuna Ludu” 1948, nr 1, s. 15; „Glos Nauczycielski” 1947, nr 35 i z 1949 r. nr 11 oraz nr 3 i 34 z 1950 r., nr 23 z 1953 r.; „Wiedza i Życie”, 1952, nr 5 i 9; „Nowa Szkola" z. 1-2 z 1951 r.; S. Skrzeszewski, Podstawowe zadania oświatowe, Warszawa 1948.

${ }^{37}$ „Glos Nauczycielski” 1948, nr 17, s. 285 (ideologizacja ZNP rozpoczęła się na drugim zjeździe delegatów ZNP, w Poznaniu w maju 1948 r., a potem podczas obrad plenarnych ZG ZNP, we Wrocławiu w październiku 1948 r.); Zob. W. Jarosiński, Realizacja planu sześcioletniego $w$ dziedzinie oświaty, „Nowa Szkoła", nr 1-2, 1951, s. 32 (w 1951 r. powołano Centralny Ośrodek Doskonalenia Kadr Oświatowych, a w 1954 r. ruszyły studia nauczycielskie, w ramach SN-ów); W. Wojtyński, Zwiazek Nauczycielstwa Polskiego w czterdziestoleciu PRL, „Przegląd Historyczno-Oświatowy, 1985, $\mathrm{nr} 2$, s. 154 (autor cytuje opinię Czeslawa Wycecha w sprawie zmian oświatowych z 1 połowie lat 50.: pracownicy oświatowi $i$ spoleczeństwo zostali odsunięci od wplywu na kierunek polityki kulturalno-oświatowej [...] szkola i nauczyciel zostali odizolowani od spoleczeństwa, a ludowe państwo pozbawilo się prężnego środka oddziaływania na szerokie kręgi spoleczne).

${ }^{38}$ L. Frydrychowska, O potrzebie istnienia Sekcji Szkolnictwa Specjalnego, „Glos Nauczycielski” nr 6, 1948; Zob. też J. Glazek, A. Rakowska, Leokadia Frydrychowska (1904-1994), „Szkoła Specjalna”, nr 4, 1995, s. 225-227 (L. Frydrychowska byla m.in. wykładowca w PIPS w latach 1945-1954, wizytatorem Wydziału Szkół Specjalnych w Ministerstwie Oświaty, członkiem komitetu redakcyjnego „Szkoły Specjalnej”).
} 
Niepokój L. Frydrychowskiej w sprawie umniejszenia roli Sekcji w pełni podzielał Kazimierz Kirejczyk, od końca 1946 r. sprawujący funkcję wizytatora w Referacie, a potem w Wydziale Szkół Specjalnych Ministerstwa Oświaty ${ }^{39}$.

Niepewność jaka zawisła nad Sekcją Szkolnictwa Specjalnego, była w pehni uzasadniona. Na przełomie 1948/49 r. Ministerstwo Oświaty opracowało dla niej nowy regulamin pracy, negatywnie oceniony podczas krajowego zjazdu okregowych podsekcji; w marcu 1949 r. prace Sekcji ograniczono w zasadzie do prowadzenia szkoleń dla nauczycieli szkół specjalnych, wobec czego Maria Grzegorzewska nie wykluczała rezygnacji z funkcji przewodniczącej ${ }^{40}$.

Podczas zjazdu podsekcji K. Kirejczyk, w referacie Polityka państwa w zwiqzku ze szkolnictwem specjalnym, starał się przekonać Ministerstwo Oświaty o potrzebie współpracy ze środowiskiem nauczycieli szkół specjalnych, reprezentowanym przez SSS ZNP. Wnioskował też o podjęcie prac zmierzających do usprawnienia selekcji oraz, z uwagi na rosnące potrzeby szkolnictwa dla przewlekle chorych, nawiązanie ściślejszej współpracy Ministerstwa Oświaty z Ministerstwem Zdrowia ${ }^{41}$.

W 1949 r. SSS ZNP zorganizowała jedną konferencję dla nauczycieli szkół specjalnych w Wejherowie. Dyskutowano na niej o bieżących sprawach szkolnictwa specjalnego, w tym o przygotowaniach Ministerstwa Oświaty do przejęcia przez państwo zakładów specjalnych prowadzonych dotąd przez organizacje samorządowo-społeczne ${ }^{42}$. Pomimo starań Sekcji inne szkolenia i konferencje skazane zostały na niepowodzenie z braku wsparcia finansowego ze strony Ministerstwa Oświaty ${ }^{43}$.

Do końca 1949 r. zasadniczym przedmiotem prac Zarządu Sekcji była kwestia jej przyszłości. Omawiano też bieżące problemy związane z funkcjonowaniem szkolnictwa specjalnego w zakresie programów nauczania, selekcji, szkoleń nauczycieli. Spore nadzieje wiązano $\mathrm{z}$ rozbudową szkół $\mathrm{i}$ zakładów specjalnych $\mathrm{w}$ ramach środków budżetowych przeznaczonych Ministerstwu Oświaty na lata 1949-195544.

${ }^{39}$ K. Kirejczyk, ZNP - Sekcja Szkolnictwa Specjalnego 50 lat pracy. Dla przyszlości dzieci upośledzonych, Warszawa 1974 (Archiwum ZNP) (Kirejczyk uważał, że realne zagrożenie wstrzymania działalności Sekcji stało się w szczególności widoczne w połowie II kadencji Zarządu Glównego SSS, czyli w 1949 r.); Zob. K. Kirejczyk, Sześćdziesią lat społecznej siużby dziecku niepelnosprawnemu "Szkoła Specjalna” nr 1, 1986, s. 84-98 (lata 1949-1955 to według autora okres „zahamowania i upadku działalności” SSS).

${ }^{40}$ K. Kirejczyk, ZNP - Sekcja..., (zjazd odbywał się w dniach od 18 do 19 marca 1949 r.) zgodnie z nowym regulaminem pracy podsekcje miały organizować konferencje i szkolenia dla nauczycieli szkół specjalnych, mając na uwadze zaznajamianie się $z$ zalożeniami pedagogiki $i$ dydaktyki socjalistycznej. W ten sposób wytyczne Instrukcji Ministerstwa Oświaty, w sprawie szkoleń ideologicznych nauczycieli szkół specjalnych, przeniesione zostały na grunt Sekcji Szkolnictwa Specjalnego; Zob. też Archiwum ZNP, Sekcja Szkolnictwa Specjalnego, syg. 680, s. 39. (ZG SSS przygotował instrukcję w sprawie konferencji i szkoleń dla nauczycieli szkół specjalnych. Znalazły się w niej zapisy o konieczności zapoznawania się nauczycieli z dorobkiem pedagogiki i dydaktyki radzieckiej. Można to uznać za dowód tego, że szkolnictwo specjalne wpisano w nurt przebudowy treści, metod i kierunków kształcenia, podobnie jak pozostale działy szkolnictwa).

${ }^{41}$ Archiwum ZNP, syg. 679, s. 82-83 (dyskusja zjazdowa).

${ }^{42}$ K.Kirejczyk, ZNP-Sekcja..., s. 105 (wszyscy uczestnicy wzięli udział w szkoleniu ideologicznym, które było głównym celem konferencji).

${ }^{43}$ Arch. ZNP, SSS, syg. 679, s. 28 (w 1949 r. okregowe podsekcje zorganizowały tylko jedno spotkanie nauczycieli szkól specjalnych, w Radomiu); Zob. też: Arch. ZNP, SSS, syg. 679, s. 14, 3, 9, 1, 117 (plany pracy sekcji okregowych SSS).

${ }^{44}$ Ibidem, s. 89-103 (na 7 posiedzeniu ZG SSS padło stwierdzenie, że: widzimy ogromny wysilek $i$ troskę Panistwa $w$ zakresie opieki specjalnej. Pragnienie, aby $i$ dziecko upośledzone moglo być wlaczone w caloksztalt wysilków narodu zmierzajacych do odbudowy i przebudowy Panstwa Ludowego). 
Rok 1950 był dla Sekcji jeszcze mniej pomyślny. Najpierw zawiesiły działalność, a następnie upadły wojewódzkie zespoły metodyczne, które Sekcja zorganizowała w porozumieniu z kuratoriami okręgów szkolnych. Był to dotkliwy cios dla jej regionalnych struktur i dowód na to, że Ministerstwo Oświaty ma inną wizję doskonalenia zawodowego nauczycieli szkół specjalnych.

Mimo to Zarząd Sekcji podtrzymywał współpracę z Ministerstwem Oświaty w zakresie organizacji kursów i szkoleń dla nauczycieli. Poszukiwanie pozaministerialnych środków finansowych zakończyło się niepowodzeniem, a wsparcie finansowe Ministerstwa Oświaty było niewystarczające na realizację ambitnych planów Sekcji. Ze środków przyznanych Sekcji przez Ministerstwo Oświaty w 1950 r. zorganizowano 2 konferencje dla nauczycieli szkół specjalnych w szkołach dla dzieci przewlekle chorych i kalekich oraz w zakładach wychowawczych.

Pierwsza konferencja odbyła się w Rabce w dniach od 7 do 21 maja 1950 r. Nauczyciele zapoznali się z tematyką i funkcją zajęć technicznych, teatrów kukiełkowych, świetlic szkolnych i harcerstwa. Najwięcej czasu pochłonęło szkolenie ideologiczne, ale i tak konferencja ta przysłużyła się pogłębieniu znajomości problematyki szkolnictwa specjalnego organizowanego dla dzieci i młodzieży przebywającej w szpitalach, sanatoriach i prewentoriach ${ }^{45}$.

Również w Rabce, w dniach od 3 do 25 lipca 1950 r., miała miejsce konferencja dla nauczycieli pracujących w zakładach wychowawczych ${ }^{46}$. Termin tej konferencji nie był przypadkowy. Towarzyszyły mu prace Ministerstwa Oświaty nad usprawnieniem kierownictwa, finansowania i zasad kształcenia zawodowego w zakładach wychowawczych.

W 1950 r. Sekcja opracowała i przekazała Ministerstwu Oświaty materiały programowe dotyczące kształcenia zawodowego w szkołach specjalnych dla upośledzonych umysłowo, w formie uwag $W$ sprawie programu nauczania $w$ szkolach specjalnych dla upośledzonych umyslowo. Za nadrzędny cel uznano przygotowywanie do możliwie samodzielnego uczestnictwa $w$ życiu społecznym oraz rozwijanie indywidualnych potrzeb ucznia w oparciu o jego fizyczne i psychiczne predyspozycje ${ }^{47}$.

W marcu 1951 r. ZNP z chwilą przekształcenia ZNP w ZZNP Sekcja została przemianowana na Komisję Produkcyjną Szkolnictwa Specjalnego (dalej KPSS ). To samo stało się z jej nielicznymi już regionalnymi delegaturami.

Działalność „produkcyjna” miała polegać na szkoleniu ideologicznym nauczycieli szkół specjalnych i tylko pod takim szyldem mogły być dla nich organizowane konferencje. Członkowie Sekcji doskonale zdawali sobie z tego sprawę i mając ograniczone pole działalności podporządkowali się dyrektywom Ministerstwa Oświaty ${ }^{48}$.

\footnotetext{
${ }^{45} \mathrm{~K}$. Kirejczyk, ZNP - Sekcja..., s. 105.

${ }^{46}$ Ibidem, s. 106 (kierownik kursu K. Kirejczyk napisał: i tym razem, jak na kursie w Wejherowie dużo miejsca i czasu zajęly wyklady z zagadnień Marksizmu-Leninizmu).

${ }^{47}$ AAN, Ministerstwo Oswiaty, syg. 1741, s. 237-240 (Sekcja postulowała, aby praca szkół specjalnych opierała się na metodzie ośrodków zainteresowań).

${ }^{48}$ AAN, ZNP, SSS, syg. 680 (w związku z przekształceniem Sekcji w Komisję Produkcyjną Szkolnictwa Specjalnego dokonano zmian statutowych. Maria Grzegorzewska, Leokadia Frydrychowska i Kazimierz Kirejczyk twierdzili, że dla dobra szkolnictwa specjalnego należy wykorzystywać wszelki dostępne ścieżki działalności, a w tym finanse zgromadzone w funduszu kształcenia ideologicznego ZNP).
} 
W 1950 r. KPSS zajmowała się oceną prac wydziałów oświaty rad narodowych w szkolnictwie specjalnym. Oceniano je na ogół negatywnie, przy czym głównym zarzutem, jaki formułowano w stosunku do ich działalności była sprawa niedostatecznego pozyskiwania lokali i budynków na szkoły specjalne i generalnie nieznajomość problematyki szkolnictwa specjalnego przez kierownictwo rad narodowych ${ }^{49}$.

W 1951 r. prace KPSS ograniczały się do wewnętrznej dyskusji o stanie szkół specjaInych i ewentualnie formułowania nielicznych dezyderatów dla Ministerstwa Oświaty w sprawie szkolnictwa specjalnego. $Z$ funkcji przewodniczącej zrezygnowała M. Grzegorzewska, której miejsce zajęła Leokadia Frydrychowska, a następnie Stefan Dziedzic ${ }^{50}$.

Również w 1951 r. powołana przez urzędników Ministerstwa Oświaty komisja programowo-metodyczna, prowadząca działalność w ramach Państwowego Ośrodka Prac Pedagogicznych i Badań Naukowych w Warszawie, przystapiła do opracowania pierwszych programów nauczania, podręczników i weryfikacji metod pracy w szkolnictwie specjalnym. Należy zauważyć, że z tego przedsięwzięcia wyłączono PIPS, który jeszcze w 1950 r. pozbawiony został funkcji naukowo-badawczej i spadł do rangi studium kształcenia nauczycieli szkół specjalnych ${ }^{51}$.

Metodę ośrodków pracy uznano za ,przeżytek pedagogiczny”. W jej miejsce szkołom specjalnym narzucano nauczanie przedmiotowe i to od pierwszych klas szkoły podstawowej ${ }^{52}$.

Przysłowiową deską ratunkową dla KPSS miała być Krajowa Konferencja ZG ZZNP, zorganizowana w dniach od 23 do 24 kwietnia 1953 r. w Warszawie. Mimo osobistego zaangażowania i wparcia ze strony prezesa ZZNP - Eustachego Kuroczki - program ożywienia prac KPSS nie został jednak przyjety. Wyjątek stanowił zapis w preliminarzu budżetowym ZZNP w sprawie organizacji kursokonferencji dla pracowników komisji selekcyjnych szkół specjalnych ${ }^{53}$.

${ }^{49}$ AAN, Ministerstwo Oświaty, syg. 1732, s. 427-430 (Sekcja twierdziła, że: niektóre prezydia WRN, PRN, MRN powinny zrewidować swój stosunek do szkót specjalnych, szczególnie do szkól dla dzieci umyslowo upośledzonych $i$ moralnie zaniedbanych. Mówiono o miejscowościach, np. Lublin i Kraków, w których szkoły specjalne znajdowały się w budynkach nieodpowiednich i urągających wszelkim zasadom higieny).

${ }^{50}$ Arch. ZNP, SSS, syg. 680 , s. $72-74$ (dezyderaty KPSS przekazywane były do Ministerstwa Oświaty. Oprócz tego w 1952 r. do Ministerstwa Oświaty przekazano memoriał, w którym wyszczególniono główne zadania stojące przed szkolnictwem specjalnym. Zaliczono do nich konieczność rozbudowy zawodowych szkół specjalnych, przygotowanie nowych podręczników i programów nauczania, budowę szkół specjalnych i lepsze przygotowanie zawodowe nauczycieli).

${ }^{51}$ Dz.U.M.O, 1950, nr 5, poz. 75. Na mocy decyzji z 14 marca 1950 r. PIPS stał się Państwowym Studium Pedagogiki Specjalnej. Decyzja ta została negatywnie oceniona wśród pracowników PIPS oraz przez Zarząd SSS ZNP; (Zob. R. Przezwański, M. Kulczycki, H. Temerson, Niektóre problemy defektologii i szkoInictwa specjalnego, „Nowa Szkoła” 1956, nr 3, s. 276-291) miejsce PIPS zajęła, utworzona wg wzorców radzieckich, Sekcja Defektologii. W 1951 r. wydano drukiem: Program nauczania w szkole dla dzieci opóźnionych w rozwoju umyslowym. Program nauczania w szkole specjalnej dla dzieci niewidomych, Program nauczania w 8-letniej szkole dla dzieci niewidomych, Program nauczania w szkole specjalnej dla dzieci oralnie zagrożonych..

${ }^{52}$ Za S. Mauersberg, M. Walczak, Szkolnictwo polskie..., s.197.

${ }^{53} \mathrm{~K}$. Kirejczyk, ZNP - Sekcja..., s. 118; K. Kirejczyk, Sześćdziesiat lat spotecznej stużby dziecku niepelnosprawnemu, „Szkoła Specjalna” nr 1, 1986, s. 84-98 (autor pisze nt. bezskutecznych prób ożywienia działalności Sekcji/Komisji); Zob. też L. Grochowski, Eustachy Kuroczko (1901-1956), „Szkoła Specjalna”, nr 4, 1989, s. 263-267 (E. Kuroczko pełnil w latach 1945-1947 funkcję dyrektora Departamentu Ogólnego w Ministerstwie Oświaty). 
W pierwszym półroczu 1953 r. ZG KPSS opracowywał program zajęć świetlicowych, zasady profilaktyki dla szkolnictwa specjalnego ${ }^{54}$.

W 1953 r. KPSS do najważniejszych zadań stojących przed szkolnictwem specjalnym zaliczyła:

- opracowanie zasad skutecznej selekcji w szkołach dla upośledzonych umysłowo,

- rozwijanie przez Ministerstwo Oświaty akcji przysposobienia zawodowego w szkołach specjalnych,

- kształcenie i dokształcanie nauczycieli,

- opracowanie i wprowadzenie do szkół nowych form pracy pozalekcyjnej.

W 1953 r. KPSS powróciła do sprawy wznowienia „Szkoły Specjalnej”. Niestety starania te były ciagle bezskuteczne. Podobnie nieudane okazały się wnioski o to, aby Ministerstwo Oświaty, wzorem lat 1946-1949, wróciło do akcji organizowania kursów szkoleniowych dla nauczycieli szkół specjalnych w okresie wakacyjnym. Powoływano się na konferencje w Rabce, Lublińcu i Sopocie ${ }^{55}$.

Oprócz tego w końcu 1953 r. KPSS, przygotowując się do uroczystości rocznicowych związanych z 10 -leciem Polski Ludowej, zorganizowała ogólnokrajową konferencję dla nauczycieli szkół specjalnych, w sali Państwowego Instytutu Głuchoniemych i Ociemniałych w Warszawie. Omawiano program uroczystości jubileuszowych oraz przy okazji sprawy selekcji i nadzoru nad szkolnictwem specjalnym ${ }^{56}$.

Przygotowania rocznicowe były kontynuowane w kolejnym 1954 r. KPSS ponownie upominała się o wznowienie „Szkoły Specjalnej”. W korespondencji z Ministerstwem Oświaty poruszano sprawy: przysposobienia zawodowego, zajęć pozalekcyjnych, sieci szkolnej, produkcji podręczników szkolnych oraz pomocy naukowych. Nie ma materiałów archiwalnych, które potwierdzałyby współpracę Ministerstwa Oświaty z KPSS w powyższych sprawach ${ }^{57}$.

W 1955 r. tylko w jednym przypadku KPSS zaznaczyła swoje istnienie. Negatywnie oceniła zarządzenie Ministerstwa Oświaty, które pomimo sprzeciwów i niezadowolenia nauczycieli szkół specjalnych, zakazywało stosowania metody ośrodków pracy w szkorach specjalnych ${ }^{58}$.

Pierwsze wyraźne oznaki ożywienia prac KPSS pojawiły się dopiero wiosną 1956 r. Wskazuje na to tematyka marcowego zebrania, które odbyło się pod hasłem Wznowienie dzialalności Sekcji Szkolnictwa Specjalnego przy ZG ZNP. Uczestniczyli w nim: przewodniczący KPSS - Stefan Dziedzic, Wacław Tułodziecki, Leokadia Frydrychowska, Janina Doroszewska i Otton Lipkowski. Do priorytetowych zadań zaliczono: wznowienie „Szkoły Specjalnej”, nakłonienie Ministerstwa Oświaty do ponownego przekształcenia

\footnotetext{
${ }^{54}$ Archiwum ZNP, SSS, syg. 680, s. 51 (Ministerstwo Oświaty zaakceptowało, na wniosek KPSS, pracę Kirejczyka Zwalczanie upośledzeń dziecięcych. Zamierzano wydać ją drukiem).

${ }^{55}$ K. Kirejczyk, ZNP... (w 1953 r. zorganizowano jeden kurs w Szklarskiej Porębie dla pracowników komisji selekcyjnych).

${ }^{56}$ Arch. ZNP SSS, syg. 680, s. 34-40, 120-122.

${ }^{57}$ Ibidem, s. 118-119, 135 (wyłączając pieniądze na druk „Biuletynu” przez KPSS).

${ }^{58}$ O. Lipkowski, Wyższa Szkola Pedagogiki Specjalnej im. Marii Grzegorzewskiej w Warszawie 1922-1982, Warszawa 1982, s. 62 (w 1956 r. Ministerstwo Oświaty najpierw ponownie dopuściło do szkól metodę ośrodków pracy, potem formalnie wycofalo się z zakazu jej stosowania).
} 
Państwowego Studium Pedagogiki Specjalnej w instytut (PIPS) i przywrócenie w szkołach specjalnych metody ośrodków pracy ${ }^{59}$.

Na czerwcowym, poszerzonym posiedzeniu KPSS, S. Dziedzic przedstawił referat o dokonaniach Sekcji w latach 1949-1955. Według niego był to czas zastoju, a Ministerstwo Oświaty przez kolejne zarządzenia narzucało Sekcji własny styl pracy. Uwagi Dziedzica podzielali wszyscy zebrani, w tym M. Grzegorzewska, O. Lipkowski, J. Doroszewska i W. Tułodziecki. Od Ministerstwa Oświaty domagano się wznowienia działalności wszystkich podsekcji, przywrócenia metody ośrodków pracy i podjęcia prac naprawczych w szkolnictwie specjalnym ${ }^{60}$.

Podsumowując należałoby zaznaczyć, że w latach 1948/49-1955/56 zarówno liczba szkół i zakładów specjalnych, jak i przebywających w nich dzieci i młodzieży uległa podwojeniu. W początkach roku szkolnego 1955/56 naukę rozpoczęły 353 szkoły dla ponad 35 tys. uczniów ${ }^{61}$. Niestety, w żadnym z działów szkolnictwa specjalnego, dla: niewidomych, głuchych, opóźnionych w rozwoju umysłowym, społecznie niedostosowanych, przewlekle chorych i kalekich, nie zagwarantowano powszechności nauczania.

W pierwszej połowie lat 50. problem dzieci niepełnosprawnych, a w szczególności upośledzonych umysłowo, traktowany był przez naczelne władze państwowe w pewnym sensie wstydliwie. Na gruncie wszechobecnej ideologii zrodziło się wówczas niesłuszne skądinąd założenie, że problem dziecka niepełnosprawnego ma ścisły związek z zaniedbaniami społeczno-gospodarczymi i kulturalnymi poprzednich epok. W rozumowaniu tym zakładano, że postęp ekonomiczny, idący w parze z rozwojem kulturalno-oświatowym społeczeństwa, wyeliminuje potrzebę dalszej rozbudowy szkolnictwa specjalnego. Rzeczywistość okazała się zgoła odmienna. Potwierdzały to zmiany zachodzące na polskiej scenie politycznej, a w szczególności wydarzenia polskiego października z 1956 r., w atmosferze którego dokonano rewizji dotychczasowej polityki oświatowej państwa.

Według mnie rzeczywisty stan szkolnictwa specjalnego w końcu lat 40 . i w pierwszej połowie lat 50. dobrze oddaje opinia Wacława Tułodzieckiego, który twierdził, że rozwój szkolnictwa specjalnego [...] odbywal się raczej żywiołowo: w ślad za ilościowym wzrostem placówek $i$ uczniów korzystajacych z tych placówek nie następowat planowy wzrost bazy materialnej (budynki, wyposażenie szkól i zakladów), wzrost wyksztalconych kadr pedagogicznych, pogtębienie pracy pedagogicznej ${ }^{62}$.

\footnotetext{
${ }^{59}$ Arch. ZNP, SSS, syg. 681, s. 600-605 (protokoły zebrań z marca 1956 r.).

${ }^{60}$ Ibidem, s. 577-599 (protokół z 12 czerwca 1956 r.); Zob. też K. Kirejczyk, ZNP - Sekcja... (autor twierdzi, że przyczyną zahamowania działalności SSS ZNP była również polityka Dyrektora Departamentu Szkolnictwa Ogólnokształcącego Stanislawa Dobosiewicza, który na jednej płaszczyźnie widział szkolnictwo specjalne i szkolnictwo powszechne. Lepiej układała się współpraca Sekcji z wcześniejszym dyrektorem tegoż departamentu Henrykiem Garbowskim, który lepiej znal potrzeby szkolnictwa specjalnego. K. Kirejczyk uważał, że w latach 1949-1955 uległo wstrzymaniu tempo prac Ministerstwa Oświaty, również za przyczyną działalności rad narodowych).

${ }^{61}$ Statystyka Polski, z. 67, Warszawa 1962 (zestawienie to uwzględnia szkoły specjalne podstawowe, zawodowe i licea ogólnoksztalcące dla przewlekle chorych).

${ }^{62}$ „Głos Nauczycielski” 1956, nr 26/27.
} 